Research Council, the broadcasting authorities, British Telecom and satellite and telecommunications equipment manufacturers, suggests that it is intended to coordinate views from a variety of sources, a role that in other countries might be taken by a national space agency.

Mr Keith Marshall, Under-Secretary of State in the Department of Industry, who will chair the committee, said in parliament that it would also be investigating topics such as the future programmes of the European Space Agency in telecommunications and remote sensing satellites, a satellite communications system for the Ministry of Defence and the marketing strategy of British satellite and ground-station technology abroad. He also indicated that the government would expect industry to put up all the finance for promising projects.

The committee will shortly have before it the conclusions of two reports commissioned by the government. The report of the Home Office study on direct broadcasting should be published later this month and the conclusions of the report of the Central Policy Review Staff on Britain's future in space are to be made available to the committee.

Hopes that an abbreviated version of the review body's report would be published, however, were quashed at the end of last month by a statement in the House of Commons - the government apparently fears breaching industrial confidentiality by allowing open discussion of the report. So far the only conclusions to emerge have been rather bland, such as that the United Kingdom should continue its commitment to the European Space Agency. It is to be hoped that the committee will provide a focus for wider debate. Judy Redfearn

\section{European Parliament Nuclear ban debate}

\section{Brussels}

A moratorium on nuclear power in Europe will be the subject of a debate in the European Parliament this week. Also on the agenda is a motion on the Geneva Appeal which was launched as a protest against France's fast breeder reactor, Super-Phénix.

The moratorium debate will focus on a report by Sir Peter Vanneck (European Democrat) who is strongly opposed to the idea. The report was adopted by the energy committee by 13 votes to 7 following a resolution by three independent Members of the European Parliament in December 1979. The moratorium would be used as an opportunity to look into the problem of storing nuclear waste, harmonizing safety standards and promoting widespread public discussion. In his report, Vanneck concedes the benefit of these points but feels that the cure would be more painful than the disease.

Depending on how widespread the moratorium would be, Vanneck calculates that by 1990 it would leave the Community short of between 45 and $115 \mathrm{GW}$, equivalent to 76 or 170 million tonnes of oil a year. By 1990, 34 per cent of the EEC's electricity needs will be supplied by nuclear power. Vanneck also points out that in 1975 electricity from nuclear power caused no deaths in the United Kingdom, while maritime transport (of oil and coal) caused 86 deaths per 100,000 employees and coal mining caused 23.4 deaths per 100,000 .

The underlying cause of public concern, says Vanneck, is that plutonium produced in nuclear power stations may be used for

\title{
East Germany banks on research
}

High technology will be the keynote of East Germany's economic strategy for the 1980 s, First Secretary Erich Honecker told last month's Congress of the Socialist Unity Party. An intensive drive to modernize and automate industry, he said, should save the country some 2,800 million man-hours during the next five years, primarily through the application of microelectronics and an increase in the number of industrial robots to be introduced into industry during the period from an original estimate of 9,000 to some 40,000 .

By 1985 , the country should be virtually self-sufficient in the production of microprocessors and their components. Other priority areas will include fibre optics, laser technology, industrial applications of microbiology, hydrogen and biomass energy sources and the development of new sophisticated technologies to make the maximum use of raw materials at the minimum cost in energy. (The recent shortfall and future uncertainty of coal supplies from Poland have caused planners to pay renewed attention to the country's own lower-grade fossil fuels, mainly lignite).

Although Mr Honecker's review of the work of research establishments, from the Academy of Sciences downwards, stressed the technological and applied aspects, he did pledge the party to a systematic development of basic research "as the source of new discoveries on logical relations in nature and society". The univerisities, including their extension and evening courses for fulltime workers, came in for special commendation as did the preliminary training courses for students at their future work-places.

The situation in the lower educational echelons, however, seems less satisfactory. Too few young people seem to be interested in scientific and technical subjects, and Honecker urged teachers and the media to make science and technology more attractive. Vera Rich military needs. This issue will certainly be linked with the debate on the Geneva Appeal. In October 1978, more than 30,000 French and Swiss, including a number of leading figures, signed an appeal asking the political community in Europe at large to consider alternatives to fast breeder reactors. The appeal reflects the fears of both Swiss and French living in the neighbourhood of the 1,250 MW Super-Phénix fast breeder reactor under construction at Greys Malville in France.

The Council of Europe had held public hearings on breeder reactors in 1979. The present motion, if adopted, would call on all governments concerned to suspend work connected with breeder reactor projects. The EEC itself does not directly contribute to any fast breeder construction programme. The European Commission, however, is preparing a report on the state of the nuclear fuel reprocessing industry.

Both debates, are nevertheless rearguard actions of the anti-nuclear group in the parliament. Most parliamentarians, as previous resolutions have shown, are firmly in the nuclear camp. But the antinuclear minority represents nearly a fifth of the members, who are effective in keeping up pressure on the Commission and member states.

Jasper Becker

\section{British countryside}

\section{Ever onward}

The British government's Wildlife and Countryside Bill - regarded as the last opportunity for major legislation on nature conservation matters this century is likely to generate as much controversy during its passage through the House of Commons as it did in the House of Lords earlier this year. The Lords considered a record 560 amendments to the bill and defeated the government on seven of them. Many of the arguments thrashed out then, on numerous topics relating to nature conservation, will be raised again, with the government trying to reverse some of the Lords amendments and various lobbyists trying to introduce more.

During the bill's second reading in the Commons last week, $\mathrm{Mr}$ Michael Heseltine, Secretary of State for the Environment, said that the government was still convinced that conservation would not be well served by compulsion. This is the chief bone of contention over clauses in the bill relating to the protection of sites of special scientific interest (SSSIs). In the Lords, the conservation lobby attempted - unsuccessfully - to amend clauses giving statutory protection to a few specially selected SSSIs to cover all such sites. The debate is likely to continue in the House of Commons committee appointed to debate the bill in detail.

The committee, which began sitting on 5 May, has 20 members, including Keith Hampson and Hector Munro for the 